\title{
IAMJ
}

INTERNATIONAL AYURVEDIC MEDICAL JOURNAL

\section{OSTEOARTHRITIS IN POST-MENOPAUSAL WOMEN - AN APPROACH THROUGH AYURVEDA}

\author{
Sindhura A. S ${ }^{1}$, Abdul Khader ${ }^{2}$ \\ ${ }^{1} \mathrm{Ph} . \mathrm{D}$. Scholar, ${ }^{2}$ Professor, \\ Department of Ph.D. and PG Studies in Kayachikitsa, \\ Shree Kalabyraveshwara Swamy Ayurveda Medical College, Hospital and Research Centre, \\ Bangalore, Karnataka, India.
}

\section{Email: drsindhuraas@gmail.com}

\section{https://doi.org/10.46607/iamjp04042020}

(Published online: May 2020)

\section{Open Access}

(C) International Ayurvedic Medical Journal, India 2020

Article Received: 09/05/2020 - Peer Reviewed: 17/05/2020 - Accepted for Publication: 17/05/2020

Check for updates

\section{ABSTRACT}

Menopause is a gradual and natural transitional phase of adjustment between the active and inactive ovarian function and occupies several years of women's life and involves biological and psychological changes adjustments. This period is usually associated with unavoidable manifestation of ageing process in women. With menopause, women enter an estrogen deficient phase in their lives, which accelerates the ageing process. Though Rajonivritti as a disease condition is not described separately in classical literature, Rajonivritti kala is mentioned by almost all classical texts. According to Sushrutha Samhita and other references too, 50 years is mentioned as the age of $R a$ jonivritti, when the body is fully in the grip of senility. Sandhigata Vata is a most common condition which occur during this phase because of Dhatukshaya. Sandhigata Vata can be explained under the degenerative osteoarthritis according to contemporary science. Contemporary science suggests supplementation of estrogen as hormone replacement therapy in postmenopausal osteoarthritis. Sandhigata Vata in Rajonivritti has to be understood under Dhatukshayajanya Samprapti, which throws light into the utilization of Rasayana therapy, those specific to Asthidhatu Poshana in specific. Anupahata (unimpeded) dhatu Agni, Srotus and Vyana Vayu which is responsible for the sustenance of Sharira dhatu which is being fed by their poshaka dhatus, the derangement of which leads to hormonal disorders. This article aims at understanding the concept of Sandhigata Vata in Rajonivritti, considering 
Arthava Kshaya as the Nidana. Rasayana Chikitsa throws light into the scope of alternative therapy to hormone replacement therapy which works at the level of dhatu Agni, Srotus and Vyana Vayu. Application of phytoestrogens in such condition should also be considered as the supportive line of management.

Keywords: Sandhigata Vata, Menopause, Estrogen, Rajonivritti, Rasayana, Osteoarthritis and Hormone Replacement Therapy (HRT)

\section{INTRODUCTION}

Menopause is a physiological process universally affects all women who reach midlife. Studies indicate that women complete the transition to menopause, an estimated $85 \%$ report one or more symptoms, of which about ten percent seek medical help ${ }^{1}$, necessitating the need to find effective and safe alternatives. Osteoarthritis, the most common articular disorder begins asymptomatically after menopause in the 2 nd and 3rd decades and is extremely common by age $70^{2}$.

$\mathrm{OA}$ is a chronic degenerative disorder of multifactorial aetiology characterized by loss of articular cartilage and peri-articular bone remodelling. It is probably not a single disease but represents the final end result of various disorders as joint failure. OA may cause joint pain, bony or soft tissue swelling, tenderness, bony crepitus, peri-articular muscle atrophy, bony hypertrophy, deformity and marked loss of joint motion. It commonly affects the hands, feet, spine, and large weightbearing joints, such as the hips and knees. It can present as localized, generalized or as erosive osteoarthritis ${ }^{3}$. OA strikes women more often than men and it increases in prevalence, incidence and severity after menopause ${ }^{4}$. Radiographic generalized OA is three times more common in women aged 45-64 years compared to their male counterparts. $64 \%$ of females with knee osteoarthritis suffered the onset of symptoms either peri menopausal or within 5 years of natural menopause or hysterectomy ${ }^{5}$. The manifestation of osteoarthritis after the decline of estrogen in menopause has a different pathology compared to the osteoarthritis that occur as degenerative joint disease. A better understanding of the role that estrogen and its deficiency plays in the molecular mechanisms of menopause induced osteoarthritic changes that affect the different joint structures has helped development of new and precise therapeutic strategies to prevent and/or restore damaged articular tissues in OA.

Sandhigatavata is mentioned in the context of gatavata in the classical texts. The lakshana are swelling in the joints, and pain which increases on extension and flexion of joints ${ }^{6,7,8,9,10,11}$. Osteoarthritis (OA) which is mentioned in western medicine has its similarities with the signs and symptoms of sandhigata vata.

The prevalence of degenerative diseases like Sandhigata vata increases with the commencement of parihani avastha (the phase of deterioration) after 40 years of age. Treatment principles related to aging are completely dependent on Rasayana. ${ }^{12,13}$ Rasayana chikitsa aims at maintaining the excellence of the body tissues by restoration of dhatu-agni, srotas and vyana vayu. Contemporary science suggests hormone replacement therapy (HRT) in postmenopausal osteoarthritis, considering the presence of estrogen receptors in subchondral bone.

The article aims at understanding the pathogenesis of sandhigata vata in rajonivritti and its management approach. The article aims at providing an insight towards the alternate to HRT in Ayurveda.

\section{Background:}

Estrogen plays an important role in the growth and maturation of bone as well as in the regulation of bone turnover in adult bone. Estrogen deficiency leads to increased osteoclast formation and enhanced bone resorption. In menopause estrogen deficiency induces cancellous as well as cortical bone loss. Depending on the ratio between formation and resorption, sub-chondral bone remodelling can culminate in either a sclerotic or an osteoporotic phenotype ${ }^{14}$. Estrogen deficiency in post-menopausal or peri menopausal women culminates in OA which is a Osteoporotic phenotype. Thus, in a post-menopausal women key changes in the 
subchondral bone include high bone turn over with decreased BMD and bone biomechanical structural damage in the early stages of OA, which either coincide with or precede cartilage degeneration. Subchondral bone degeneration may be the trigger for changes in the cartilage biomechanical and biochemical microenvironment, thus promoting cartilage erosion and ultimately OA progression. ${ }^{15,16}$ Estrogen deficiency may lead to increased serum IL-6 in postmenopausal patients with $\mathrm{OA}$, which has been found to promote $\mathrm{OA}$ progression. ${ }^{17}$

Estrogen-related drugs that act on both subchondral bone and cartilage are good candidates for early-stage OA treatment, especially osteoporotic OA because of its anti-resorptive property. ${ }^{18}$ These drugs are potent in antagonizing bone resorption, which can effectively decrease bone remodelling and prevent subchondral bone loss and the deterioration of microarchitecture and biomechanical properties. Thus, the protective effect of these drugs on articular cartilage may be an indirect effect through protection of the subchondral bone. Additionally, these drugs directly target cartilage tissue, preventing cartilage damage and maintaining healthy cartilage. In addition to the direct or indirect protective role of these drugs on articular cartilage, subchondral bone, and the surrounding joint tissues, including the synovium and muscle, the joint tissues themselves interact with each other, thus maintaining joint organ homeostasis as a whole and finally delaying joint degeneration. ${ }^{18}$

\section{Sandhigata Vata In Rajonivritti}

Sandhigata vata after rajonivritti can be understood under dhatukshayajanya samprapti. The prevalence of degenerative diseases like Sandhigata vata increases with the commencement of parihani avastha (the phase of deterioration) after 40 years of age. Treatment principles related to aging are completely dependent on $R a$ sayana. ${ }^{12,13}$ Rasayana chikitsa aims at maintaining the excellence of the body tissues by restoration of dhatuagni, srotas and vyana vayu.

According to Charaka Samhita, nidana sevana aggravates vata and this prakupita vata gets accumulated in rikta srotas, where there is snehadi guna kshaya and gives rise to various generalized and localized diseases. ${ }^{19,20}$ In the manifestation of Janu Sandhigata Vata the prakupita vyana vata travels along and gets lodged in Janu Sandhi where there is already existing khavaigunya, resulting in diminution of sleshaka kapha. Combined effect of all these processes manifests the symptoms of Janu Sandhigata Vata.

Menopausal syndrome does not find mention as disease in Ayurvedic literature, the reason could be women at that time belonged to a society which had Ayurveda as its health standard. They entered in old age as kalaja vridhhavastha (timely aging) and Rajonivritti (menopause) occurring at about age of 50 years passed uneventful. According to contemporary medical science, this physiological transition from reproductive to postreproductive life is associated with decline in estrogen levels.

Ayurveda considers aging as Nishpratikriya ${ }^{21}$ (changes cannot be resisted) and Swabhavabala Roga 22 (natural disease). Rajonivritti occurring in Jarapakva Shareera at the age of 50 years ${ }^{23}$ is comparable to the present-day studies showing the mean age of menopause to be 45 years.

With advancing age there is gradual diminution in the qualities of dosha, dhatu, mala, agni and oja. ${ }^{24}$ The anupahata dhatu agni, srotas and vyana vayu is responsible for the sustenance of shareera dhatu which is being fed by their poshaka dhatus ${ }^{25}$, the derangement of which leads to hormonal disorders. Artava is an upadhatu, formed from Rasa dhatu within a month after proper metabolization of rakta dhatu by its dhatvagni and bhutagni. ${ }^{26}$ The kshaya of rakta dhatu causes artava kshaya due to utarottara dhatu kshaya. Kshaya of updhatu artava and shukra, manifest as cessation of menstruation. Further, due to same reasons loss of ojas makes women more susceptible to illness. Dhatukshsya leads to vata Vitiation. With advancing age, progressive vitiation of vata due to its fundamental properties of ruksha, chala, laghu, bahu, shighra and sheeta, further precipitates the soshana and kshaya of different dhatu. This degeneration manifests as Indriya kshaya (loss of this perceptive powers of sensory organs), Bala kshaya (loss of strength) and Virya kshaya 
(loss of reproductive strength). This may explain various symptoms of menopause related to degenerative changes in body ${ }^{27}$. Ama, formed due to mandagni causes stroto avarodha, which in turn increases Medodushti and decreases the nutrient supply to subsequent dhatus namely asthi (bone/skeletal system), majja (bone marrow), and shukra (sperm/ fertility promoting substance $)^{28}$. One of the functions of dhatu is shareera dharana (bear/ supports the bodies frame). Among the dhatu, asthi dhatu is specific for shareera dharana. According to the principal of Ashraya- aashreyee bhava, ${ }^{29}$ asthi dhatu is the seat of vata dosha, and asthi and vata are inversely proportionate to each other ${ }^{30}$. Increase of vata vitiating factors will cause decrease of asthi dhatu. With advancing age vitiating vata leads to kshaya of asthi dhatu (decreased bone density). It can be compared with osteoporosis.

Further, vitiated vata due to kshaya of rasa dhatu when gets lodged in sandhi, causes sandhigata vata. This may explain the increased incidence of skeletal ailments like arthralgia, osteopenia, osteoporosis, osteoarthritis and increased predisposition to fractures as seen during menopause. The menopause transition represents a period of dynamic change from middle age to old age. This transition from pitta dominance to vata dominance causes most of the symptoms of menopause for Pitta is more akin to metabolic activities and vata have an active role in degeneration.

\section{Approach Towards The Management}

Charaka Samhita has mentioned common treatment for vata vyadhi i.e., repeated use of snehana and swedana, basti and mrudu virechana. ${ }^{31}$ Other classical literature have mentioned the treatment for Sandhigata vata in specific, i.e. snehana, upanaha, bandhana, agnikarma, unmardana. . $2,33,34,35$ and other shamanoushadhi.

In Sushrutha Samhita it is mentioned that the given description of sandhi is only for asthi sandhi. ${ }^{36}$ Dalhana in his commentary Nibandha Sangraha states that sandhi means asthyashrita Sandhi. ${ }^{37}$ So Sandhigata vata is considered as Asthi-Sandhigata vikara. Asthi and sandhi are the moolasthana of majjavaha srotas. Majja kshaya makes the person afflicted by vataroga. ${ }^{38}$ Considering the above points, Asthi majjagata vata chikitsa is adopted in Sandhigata vata where bahya and $a b$ hyantara sneha is employed. ${ }^{39}$ Charaka Samhita mentions Panchakarma chikitsa especially Basti with ksheera and sarpi processed with tikta dravyas are useful in asthyashrita vyadhi. ${ }^{40}$

Considering osteoarthritis in postmenopausal women as Osteoporotic phenotype, contemporary science proposed estrogen as HRT to treat the condition. To treat the menopause means to relieve the discomfort and disorder due to hormone deficiency and at the same time to ward off degenerative processes of old age or at least to mitigate their effects and slow down their rate of advance. HRT solves only half of the problem but to provide optimum physical and mental fitness search for alternatives other than HRT are warranted.

So, considering sandhigata vata in rajonivritti as a degenerative disease in parihani avastha of an individual due to derangement in dhatu agni, srotas and vyana $v a y u$, the treatment modalities can be designed as follows ${ }^{41}$ :

1. Maintaining the excellence of anupahata (unimpeded) dhatu agni, srotus and vyana vayu which is responsible for the sustenance of sharira dhatu which is being fed by their poshaka dhatus.

2. Regular consumption of artava bahukala sthapana hetu $^{42}$.

3. As Sandhigata Vata is a disease of old age, Rasayana chikitsa is employed.

4. Those treatment methods which are directly mentioned as the chikitsa sutra of Sandhigata Vata. Those are snehana, upanaha, agnikarma, bandhana, mardhana and swedana ${ }^{32,33,34,35}$.

5. The general vatavyadhi chikitsa applicable to Janu Sandhigata Vata based on the lakshana and sthana of the disease like virechana and basti karma ${ }^{31}$.

6. Considering sandhigata vata as asthivaha srotho dusti, asthi majjagata vata chikitsa is adopted in sandhigata vata where bahya and abhyantara sneha is employed ${ }^{43}$.

7. Considering Sandhigata Vata as asthi-ashritha vata vyadhi, Panchakarma chikitsa especially basti with ksheera and sarpi processed with tikta dravyas are useful ${ }^{44}$. 


\section{DISCUSSION}

Two main components which need to be addressed in women having problems during menopause are advancing age and allied changes, and menopausal symptoms. An intellectual adoption of the suitable treatment options which includes planned usage of multiple variables as per individual needs is best approach for its management.

Rasayana Chikitsa, is a unique concept of Ayurveda. It provides a comprehensive physiologic and metabolic restoration for aging. Rasayana chikitsa is mainly used for maintaining the health of healthy individuals although it can be used for diseased also. The word 'rasa' in Rasayana refers to the rasa dhatu in the context of rasadi sapta dhatu and to the pharmacodynamic properties of a drug in the context of rasa guna etc. Ayana means circulation, the measures by which one is capable of getting the nourishing rasa. Acting through a complex and comprehensive mechanism of rasasamvahana (circulation of nutrient juices), dhatu agni, srotas and vyana vayu it nourishes bodily tissues through micro- nutrition, thus helping in regeneration, revival and revitalization of dhatu.

Acting at all levels of rasa are the drugs such as Draksha (Vitis vinifera Linn.), milk, Shatavari (Asparagus racemosus), Salaparni (Desmodium gangeticum) etc. they act by enriching the nutritional value of the circulating plasma. Research studies have shown that drugs like Ashwaganda and Shatavari have anti osteoporotic and phytoestrogenic properties. Study was carried out on aqueous and methanolic extracts of Asparagus racemosus root in ovarimectomized rats to evaluate the antiosteoporotic activity. Study showed significant effect on mineralisation, ossification and osteoclastic activity suppression in histopathological examination. It showed significant results in biochemical parameters, also reduced serum alkaline phosphatase activity, serum calcium significantly and also inhibited the ovarimectomized induced excessive loss of calcium in urine. Shatavari is a phytoestrogen rich herb. Saponins (in the form of shatavarins) and flavonoids (in the form of isoflavonoids) are phytoestrogens. It has high calcium levels in the roots. It has anti-inflammatory properties and possess wide range of fat- and water-soluble vitamins preventing inflammation in osteoarthritic patients. Shatavari enhances the bone formation and decreases the bone resorption ${ }^{45,46}$.

Sushruta Samhita explained the principle as tatra swayoni vardhana dravya prayogah pratikaraha (Su.Su15). Swayoni vardhana chikitsa helps in regeneration, revival and revitalization of dhatu. Acting at the level of Agni i.e. at the level of digestion and metabolism are the drugs such as Pippali (Piper Longum Linn.), Haritaki (Terminalia chebula), Citraka (Plumbago zylenica), etc. they improves the digestion, absorption and metabolism, and has anabolic effect. Acting at the level of Srotamsi (the microcirculatory channels carrying nutrition to the tissues) are the drugs such as Guggulu (Commiphora mukul), Pippali (Piper Longum Linn.), Rasona (Allium cepa), etc. These $R a$ sayana cleans and activate the micro- circulatory channels i.e. Sroto Shuddhi leading to improved tissue health and their quality ${ }^{47}$. The proper functioning of vyana vayu helps in proper circulation of rasa dhatu through the srotus.

Vagbhata in Shareera sthana of Astanga sangraha mentions arthava bahu kala sthapana hetu. Women who are habituated to the use of ghee, milk, etc daily, who are cheerful, who belong to kapha constitution will retain the arthava for long time, delaying the menopause $^{42}$. Ksheera and ghrita are considered among nitya sevaneeya rasayana dravyas.

For symptoms occurring due to transition from madhayamavastha (pitta dominant phase) to vridhhavastha (vata dominant), use of Ghrita can be recommended. Ghrita is Vata-pitta shamaka, Balya, Agnivardhaka, Madhura, Soumya, Sheeta-Virya, Shulahara, Vrishya and Vayasthapaka ${ }^{48}$. Thus, it not only pacifies Vata and Pitta but also improves the general condition of the body and acts as a rejuvenator of the body. Ghrita is Yogavahi ${ }^{49}$ (special affinity to carry and to potentiate the actions of the main drug to which it is mixed) and thus helps in increasing bioavailability of other drugs without losing its own property. Medicated ghrita such as Amalaki Ghrita, Shatavari ghrita, Guduchi ghrita, Chitraka ghrita, Panchakola ghrita and Panchatikta ghrita are various medicated Ghrita 
preparations suitable for menopausal women. Ksheera by madura rasa, guru snigdha guna and sheeta veerya is vata-pitta shamaka. It is medhya, rasayana, vrishya and jivaniy $a^{50}$. Milk basic protein increases bone mineral density and improves bone metabolism in healthy young women ${ }^{51}$. It prolongs the reproductive lifespan and counteracts the adverse effects of reactive oxygen species on the number and quality of ovarian follicles. Appropriate applications have potential to ward off problems related not only to aging and natural menopause but also in menopausal symptoms induced due to surgical, medical and other reasons. Aging though considered Nishpratikriya has been dealt scientifically in Ayurveda. Emphasizing Ayu (lifespan), its chikitsa (therapeutics) is called as Vaya Sthapana (age stabilizing). Ayurveda Avatarana has been guided by zeal of mankind to have Dirgha Hitakara and Sukhakara Ayu (a longer healthy and happy life). It recommends the countering of aging and related changes by use of Vayasthapaka drugs (age stabilizers), to rejuvenate the aged body by Jeevneeya drugs (vitalisers) and for allied aging problems Jarachikitsa i.e. Rasayana Chikitsa (rejuvenating process and formulations).

\section{CONCLUSION}

Menopause is related with the vatadosha dominated stage of life. Menopause is attainted at the age of 50 years according to the various literature and with the commencement of parihani avastha of an individual. In this stage the seven dhatu undergoes gradual deterioration. Among which asthi kshaya and sandhi shaithilya occurs in asthidhatu kshaya. Arthritis and osteoporosis occur in this condition. Osteoarthritis in post menopause stage is considered as a phenotype of osteoarthritis which include high bone turn over with decreased BMD of subchondral bone. In the above phenotype of osteoarthritis, along with the regular management protocols of sandhigata vata, the attempt has to be made to check the bone resorption. Achievement of Anupahata (unimpeded) dhatu agni, srotas and vyana vayu is responsible for sustainance of shareera dhatu which can be achieved by Rasayana chikitsa. It is quoted in Astanga Sangraha that regular consumtion of ksheera and ghrita preserves the artava for longer duration, and hence delays menopause. The drugs having phytoestrogen properties like ashwaganda, shatavari are good candidates for early-stage OA treatment, especially osteoporotic OA because of its anti-resorptive property. These drugs are potent in antagonizing bone resorption, which can effectively decrease bone remodeling and prevent subchondral bone loss and the deterioration of microarchitecture and biomechanical properties. Additionally, these drugs directly target cartilage tissue, preventing cartilage damage and maintaining healthy cartilage. In addition to the direct or indirect protective role of these drugs on articular cartilage, subchondral bone, and the surrounding joint tissues, including the synovium and muscle, the joint tissues themselves interact with each other, thus maintaining joint organ homeostasis as a whole and finally delaying joint degeneration.

\section{REFERENCES}

1. http://www.cdc.gov/reproductivehealth/womensrh/m enopause.htm

2. Longo, Fausi, Harper, Kasper, Hauser, James, Loscalzo, Harrison's Principle of Internal medicine, 18th edition, page no: 2828 .

3. Annil Mahajan et.al OSTEOARTHRITIS AND MENOPAUSE; J Indian Rheumatol Assoc., 2005; 13: 21-25.

4. Annil Mahajan et.al OSTEOARTHRITIS AND MENOPAUSE; J Indian Rheumatol Assoc., 2005; 13: 21-25.

5. Jorge A Roman et.al OSTEOARTHRITIS ASSOCIATED WITH ESTROGEN DEFICIENCY; Arthritis Research \& Therapyvolume 11, Article number: 241 (2009).

6. Agnivesha, Charaka Samhita chakrapanidhattha virachita, edited by vaidhya yadavji trikamji acharya, chawkamba publications, third edition, chikitsasthana, vatavyadhinidhana 28th chapter, 1941; 618.

7. Acharya Sushrutha, Sushrutha samhita ayurveda tatwa sandeepika, hindhivyakya, vaijnanikavimarsha- tippanisahita prathamabhaga by kaviraja ambikadhattha shastri, chawkamba samskritha samsthana, reprint, nidhanasthana vatavyadhinidana1, 2007; 230.

8. Vagbhata, Ashtanaga hridaya, vidhyothini hindhi commentary by kaviraja athrideva gupta, edited by vaidhya yadhunanda upadhyaya, chawkamba prakashana, reprint, nidhanasthana, 2007; 15: 277. 
9. Anonymous, Yogaratnakara Uttarardha with Vidyotini Hindi commentary by Vaidya Lakshmipati Shastri, Edited by Bhisagratna Bramha Shankar Shastri, Chaukhamba Prakashan, Varanasi, edition Reprint, vatavyadhi nidhana, 2010; 505.

10. Bhavamishra, Bhavapraksha, Uttarardha, Bhrama Shankara Shstry's Vidyotini teeka, Chaukhamba Samskruta Samsthana, Varanasi, 8th edition, Reprint, vatavyadhiadhikara, 2003; 227.

11. Vaidya Shodala, Gadanigraha, Shri Indradeva Tripati's Vidyotini Commentry, Chaukhamba samskruta samsthana, Varanasi, Dwithiya kayachikitsa Kanda, Edition reprint vatarogadhikara, 2011; 464.

12. Sastri K, Chaturvedi G, editors. Chikitsasthan. Varanasi: Chaukhamba Bharti Academy; 1998. Agnivesha, Charak Samhita, Vidyotini; pp. 1-64.

13. Dalhanacharya, sushrutha samhita sutrasthana,1, of Sri Dalhanacharya and the nyayacandrika panjika of sri gayadasacharya on nidanasthana, edited by vaidhya jadavji trikamji Acharya, chaukhamba orientalia, Varanasi, 2014., pn 7.

14. Ya-Ping Xiao et.al Are estrogen related drugs new alternatives for the management of Osteoarthritis? Arthritis Research \& Therapy, 2016; 18: 151, 28 June 2016.

15. Dr. A.S. Sindhura et.al, OSTEOARTHRITIS IN MENOPAUSAL WOMEN, CONCEPTS AND MANAGEMENTS, European Journal of Biomedical and Pharmaceutical Sciences, Volume 6, Issue 12, 2019, pn 398 402, http://ejbps.com/ejbps/abstract_id/6298

16. Bellido M, Lugo L, Roman-Blas JA, Castaneda S, Caeiro JR, Dapia S, et al. Subchondral bone microstructural damage by increased remodelling aggravates experimental osteoarthritis preceded by osteoporosis. Arthritis Res Ther., 2010; 12: R152. [PubMed] [Google Scholar]

17. Sniekers YH, Weinans H, van Osch GJ, van Leeuwen JP. Oestrogen is important for maintenance of cartilage and subchondral bone in a murine model of knee osteoarthritis. Arthritis Res Ther., 2010; 12: R182. [PubMed] [Google Scholar]

18. Dr. A.S. Sindhura et.al, OSTEOARTHRITIS IN MENOPAUSAL WOMEN, CONCEPTS AND MANAGEMENTS, European Journal of Biomedical and Pharmaceutical Sciences, Volume 6, Issue 12, 2019, pn 398 402, http://ejbps.com/ejbps/abstract_id/6298

19. Agnivesha, Charaka samhita with Ayurveda Deepika commentary by Chakrapani dutta, edited by
20. Vaidya Jadavaji Trikamji Acharya, Varanasi: Chaukhamba Surabharathi prakashan, Chikitsa Sthana, 2009; 28: 617 .

21. Chakrapani, Agnivesha. Charaka samhita with Ayurveda Deepika commentary by Chakrapani dutta, edited by Vaidya Jadavaji Trikamji Acharya, Varanasi: Chaukhamba Surabharathi prakashan, Chikitsa Sthana, 2009; 28: 617. Am. J. Epidemiol. (2001) 153 (9): 865-874.doi: 10.1093/aje/153.9.865.

22. Shastri A D, Sushrut Samhita of Maharishi Shusruta with Ayurvedatatvasandipika Hindi commentary, Sutra Sthan, Chapter 35, Verse 36, Chaukhambha Sanskrit

23. Prof. Srikantha Murthy K.R, 2nd Edi. Sushrut Samhita vol-1, Shareer Sthan, Chapter 3, Verse 11, Varanasi, Chaukamba, 2004, P.P. 37

24. Atridev Gupta, Edi, 2nd edition, Charak Samhita, Viman Sthan, Chapter 8, Verse 22; (also Sushrut Samhita, Chapter 15, Verse 22

25. Agnivesha,Charaka Samhita, Ayurveda dipika commentary by Chakrapanidutta, edited by Vaidya yadavji trikamji acharya 1941,chawkamba publications, third edition, Chikitsasthana, Vatavyadhinidhana $28^{\text {th }}$ chapter, 37 verse, page no. 618 .

26. Gupta A, editor. Asthanga Hrudaya Sharira Sthana, Chapter 1, Verse 24 with Vidyotini Hindi comm; Varanasi: Chaukhamba Sanskrit Sansthana; 1991 p. 364.

27. WHO Scientific Group. Research on the menopause in the 1990s. World Health Organ Tech Rep Ser. 1996, 866, p. 1-107.

28. Agnivesha, Charaka, Dridhabala. Vaidya Jadavaji Trikamji Aacharya., editor. Charaka Samhita, Sutra Sthana, Chapter 21, Ashtauninditeeya Adhyaya, Verse 4. 5th ed. Varanasi: Chaukhamba Sanskrit Sansthan; 2009. p. 116.

29. Vagbhatt, Astang Hridaya, Sutra Sthan, Chapter 12, Verse 26-28; Astang Hridaya Sutra Sthan, Chapter 11, Verse 26

30. Vagbhatt, Astang Hridaya, Chapter 13, Verse 58

31. Agnivesha,Charaka Samhita, Ayurveda dipika commentary by Chakrapanidutta, edited by Vaidya yadavji trikamji acharya, chawkamba publications, third edition, Chikitsasthana, Vatavyadhinidhana 28th chapter, 1941; 618.

32. Acharya Sushrutha, Sushrutha Samhita, Ayurveda tatwa sandeepika, Hindhivyakya, Vaijnanikavimarsha- tippanisahita prathamabhaga by Vaidhya Priyavath sharma, Chawkamba samskritha samsthana, reprint, Chikitsasthana Vatavyadhi Chikitsa, 2007; 26. 
33. Anonymous, Yogaratnakara Uttarardha with Vidyotini Hindi commentary by Vaidya Lakshmipati Shastri, Edited by Bhisagratna Bramha Shankar Shastri, Chaukhamba Prakashan, Varanasi, edition Reprint, Vatavyadhi Nidhana, 2010; 505.

34. Govind Dasa, Bhaishajya Rathnavali, Edited and Enlarged by Bhisagratna Shri Brahmanshankar Mishra and Shri Kaviraja Ambikadatta Shastri Ayurvedacharya, Editor Shri Rajeshwadatta Shastri, Chaukhambha Prakashan, Varanasi, Edition, Vatavyadhi Chikitsaprakaranam, 2011; 373.

35. Chakradatta, with Vaidhyaprabha hindhi vyakya, Shri Jagadeeshaprasada tripati, Chaukamba publications, chapter on Vatavyadhichikitsa, 182.

36. Sushruta, Sushruta Samhita with Nibandha Sagraha commentary by Dalhana, edited by Vaidya Jadavaji trikamji Acharya. Varanasi: Chaukhamba Surabharathi prakashan, Shareera Sthana, 1997; 5: 367.

37. Dalhana, Sushruta samhita with Nibandha Sagraha commentary by Dalhana, edited by Vaidya Jadavaji trikamji Acharya. Varanasi: Chaukhamba Surabharathi prakashan, Shareera Sthana, 1997; 5: 367.

38. Vriddha Vagbhata, Astanga Sangraha, edited by Shri. Pandit Lalachandrashastry Vaidhya, Published by Shri Vaidhyanatha Ayurveda Bhavana, Pvt. Ltd, Nidana Sthana, 1: 309.

39. Agnivesha, Charaka Samhita, Ayurveda dipika commentary by Chakrapanidutta, edited by Vaidya yadavji trikamji acharya, chawkamba publications, third edition, Chikitsasthana, 2009; 28: 621.

40. Agnivesha, Charaka Samhita, Ayurveda dipika commentary by Chakrapanidutta, edited by Vaidya yadavji trikamji acharya, chawkamba publications, third edition, Sutrasthana, 2009; 28: 180.

41. Dr. A.S. Sindhura et.al, SANDHIGATA VATA-CONCEPTS AND MANAGEMENT- A REVIEW ARTICLE , World Journal of Pharmaceutical and life sciences, Volume 6, Issue 1, 2020, pg 83-90, http://wjpls.org/home/current_issues

42. Vagbhata, Astanga Sangraha, Translated By Prof. K. R. Shrikanta Murthy, Chaukhambha Orientalia, 2009 Edition, Vol L1, Shareerasthana 1, 64 Verse, Pn 15

43. Agnivesha, Charaka Samhita, Ayurveda Dipika Commentary By Chakrapanidutta, Edited By Vaidya Yadavji Trikamji Acharya, Chawkamba Publications, Third Edition, Chikitsasthana, 2009; 28: 621.

44. Agnivesha, Charaka Samhita, Ayurveda Dipika Commentary By Chakrapanidutta, Edited By Vaidya Yadavji
Trikamji Acharya, Chawkamba Publications, Third Edition, Sutrasthana, 2009; 28: 180.

45. Dr. Pooja S.K.Rai Et.Al, Role Of Shatavari In Management Of Early Osteoarthritis, IJAR, Sept 2019, Volume 7, Issue 9, Pn 460-464

46. Jasmine Japee, A Comparative Study On Shatavari And Kukkutanda Twak Bhasma In Minimising The Risk Of Postmenopausal Osteoporosis, AYU Journal, 2009, Volume 30, Issue 3, Pn. 314-317

47. K. K. Dwivedi, M. Paul, P.B. Behere And R.H. Singh. The Concept Of Aging In Ayurveda Ancient Science Of Life, Vol No. XIV Nos. 3 \& 4, January - April 1993, Pages $377-387$

48. Dr. Anant Ram Sharma, Edi. Sushrut Samhita Edited With Susrutavimarsini Hindi Commentary, Sutra Sthan. 96. Vol. 45. Varanasi: Chaukhambha Surbharati Prakashan; P. 366.

49. Acharya YT, Editor. Charaka, Charaka Samhita, With Chakrpaanidatta; Ayurved Dipika Commentary. 1st Ed. Varanasi, Uttar Pradesh, India: Chaukhambha Orientalia; 1984. P.166

50. Bhavamishra: Bhavaprakasha, Madhyamakhanda Edited With Vidhyotini Hindi Commentary By Bhisagratna Sri Brahmashankara Mishra Shastry, Varanasi, Chaukambha Sanskrit Samsthan, Vol 1, P.No 398

51. K. Uenishi, H Ishida, Milk Basic Protein Increases Bone Mineral Density And Improves Bone Metabolism In Healthy Young Women., Osteoporosis International, Volume 8, Issue 3, 2007, Pn. 385-390.

\section{Source of Support: Nil \\ Conflict of Interest: None Declared}

How to cite this URL: Sindhura A. S \& Abdul Khader: Osteoarthritis In Post-Menopausal Women - An Approach Through Ayurveda. International Ayurvedic Medical Journal \{online\} 2020 \{cited May, 2020\} Available from: http://www.iamj.in/posts/images/upload/2340_2347.pdf 